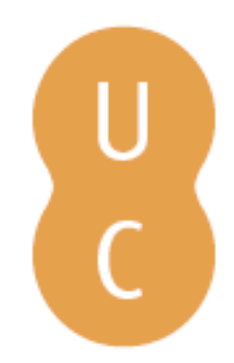

\title{
pommalina
}

\section{Observations on wildfire spotting occurrence and characteristics in Greece}

\author{
Autor(es): $\quad$ Athanasiou, Miltiadis; Xanthopoulos, Gavriil \\ Publicado por: Imprensa da Universidade de Coimbra \\ URL \\ persistente: URI:http://hdl.handle.net/10316.2/44582 \\ DOI: $\quad$ DOI:https://doi.org/10.14195/978-989-26-16-506_65
}

Accessed : $\quad$ 26-Apr-2023 09:09:23

A navegação consulta e descarregamento dos títulos inseridos nas Bibliotecas Digitais UC Digitalis, UC Pombalina e UC Impactum, pressupõem a aceitação plena e sem reservas dos Termos e Condições de Uso destas Bibliotecas Digitais, disponíveis em https://digitalis.uc.pt/pt-pt/termos.

Conforme exposto nos referidos Termos e Condições de Uso, o descarregamento de títulos de acesso restrito requer uma licença válida de autorização devendo o utilizador aceder ao(s) documento(s) a partir de um endereço de IP da instituição detentora da supramencionada licença.

Ao utilizador é apenas permitido o descarregamento para uso pessoal, pelo que o emprego do(s) título(s) descarregado(s) para outro fim, designadamente comercial, carece de autorização do respetivo autor ou editor da obra.

Na medida em que todas as obras da UC Digitalis se encontram protegidas pelo Código do Direito de Autor e Direitos Conexos e demais legislação aplicável, toda a cópia, parcial ou total, deste documento, nos casos em que é legalmente admitida, deverá conter ou fazer-se acompanhar por este aviso.

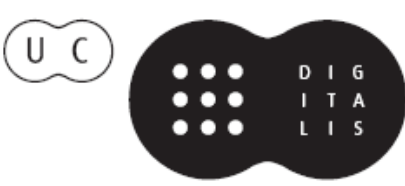




\section{ADVANCES IN}

\section{FOREST FIRE RESEARCH}

\section{8}

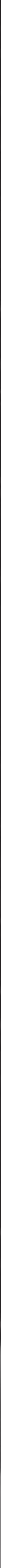




\title{
Observations on wildfire spotting occurrence and characteristics in Greece
}

\author{
Miltiadis Athanasiou ${ }^{1 *}$; Gavriil Xanthopoulos ${ }^{2}$ \\ ${ }^{1}$ Wildfire Management Consulting and Training. 8 Thoma Paleologou st., Acharnes, 13673, \\ Athens, Greece, \{info@m-athanasiou.gr*\} \\ ${ }^{2}$ Hellenic Agricultural Organization "Demeter". Institute of Mediterranean Forest Ecosystems. \\ Terma Alkmanos, Ilisia, 11528, Athens, Greece, \{gxnrtc@fria.gr\}
}

\begin{abstract}
This paper presents a study on the phenomenon of spotting in some of the most common forest vegetation types in Greece, during wildfires in the 2007-2017 period. Monitoring and documenting selected wildfires during this period, noting the appearance or absence of spot fires and the prevailing conditions at the time, a database of 166 field observations was developed. The database includes information on the number of observed spot fires $(\mathrm{N} \kappa)$, the in situ measured relative humidity $(\mathrm{RH}, \%)$ values, the wind speed, the forest fuel type where the firebrands had landed, namely maquis, phrygana and grasses, the maximum spotting distance $(\mathrm{D} \kappa, \mathrm{m})$ from the fire perimeter, the fire perimeter segment (head or flank) where the firebrands came from, and the fire type, namely surface, passive crown, active crown and plume dominated fire.

The database was analyzed first by examining the correlation of $\mathrm{RH}$ values with $\mathrm{N \kappa}$ for the three fuel types. An ordinal variable named $\mathrm{K} \kappa$ was created in order to represent the following four empirical classes: a) no spotting $(\mathrm{N} \kappa=0, \mathrm{~K} \kappa=0)$, b) rare spotting $(\mathrm{N} \kappa<3, \mathrm{~K} \kappa=1)$, c) limited spotting $(3 \leq \mathrm{N} \kappa \leq 9, \mathrm{~K} \kappa=2)$ and d) profuse/massive spotting ( $\mathrm{N} \kappa \geq 10, \mathrm{~K} \kappa=3$ ). At $\mathrm{RH}$ values higher than $46 \%$, no spotting ignition was recorded. Massive spotting that triggered extreme fire behavior, was documented for RH values lower than $17 \%$. The $\mathrm{RH}$ thresholds for spotting occurrence that were identified for the three forest fuel types on which the

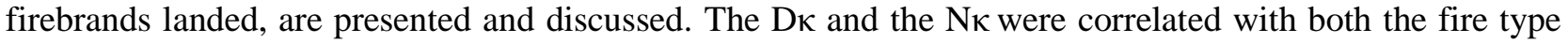
and the fire segment on which they were observed. Their descriptive statistics are also presented and discussed. The study confirmed the great spotting potential of the plume dominated wildfires, both in regard to spotting distance and the number of spot fires.
\end{abstract}

Keywords: Spotting, Spot fire, Forest fire, Wildfire behaviour, Firefighting, Greece

\section{Introduction}

Spotting ignition is one of the three significant mechanisms of wildfire spread. It can be considered as a discontinuous fire spread mechanism (Koo et al. 2010) that is synonymous with solid mass transport (Albini1979, Alexander 2009). The transport of burning fire embers outside the fire perimeter, is a cause of serious concern to firefighters because it affects fire behaviour and difficulty of control and poses a serious threat for them and for civilians.

Spotting involves the source of firebrands, how far they travel, and the probability of ignition on landing (Rothermel 1983). It is mainly caused by lofted firebrands, including burning tips of branches, cones, and pieces of bark, that fly and land beyond the main fire perimeter, but may also be caused by burning cones or pieces of wood rolling down steep slopes (Van Wagner 1988). The type of forest vegetation that is burning is important for the creation of firebrands.

The probability of ignition at the point where a firebrand lands, is a function of both firebrand size and temperature. It has been found that as firebrand size is reduced, increased temperature is required for ignition (Hadden and Scott 2011). Additionally, the probability of ignition depends on the characteristics of the dead fuels where the firebrand lands, such as fuel quantity, dimension (fineness), arrangement (compactness and continuity) and fuel moisture content (FMC, \%). Atmospheric relative

Advances in Forest Fire Research 2018 - Page 588 
humidity (RH, \%) affects directly the FMC of dead fuels, the effect being more dramatic and the response faster for the finer ones. Thus, significant differences in spotting may exist, depending on the forest vegetation properties. Firebrands in the flaming phase are more capable to ignite fuel beds with no air flow than the ones in the glowing phase with air flow (Ganteaume et al. 2009) while when fire danger is high, the ignition probability of flaming firebrands that land on fine fuels, approaches $100 \%$ (Ellis 2012).

A spotting distance of up to 200 meters $(\mathrm{m})$ corresponds to short-range spotting and is common in high intensity wildfires, while distance values between $200 \mathrm{~m}$ and 1 kilometer $(\mathrm{km})$ (Bushfire CRC 2009) or between $200 \mathrm{~m}$ and $2 \mathrm{~km}$ (Alexander 2009) can be considered as medium-range spotting. A spotting distance greater than 1 or $2 \mathrm{~km}$, which is very common in some forest types, such as the eucalypt forests of Australia, can be considered as long-range spotting.

The number of firebrands generated and the rapidity of development of the spot fires, determine the magnitude of the phenomenon and its effect on wildfire behaviour (Ellis 2012). Spotting usually exacerbates fire suppression activities and plans, is the leading cause of loss of structures in fires in Wildland Urban Interface (WUI) areas and is a major concern regarding the safety of firefighters and the public (Alexander 2009).

In Greece, spotting occurs often in all of its Mediterranean vegetation types, such as the Mediterranean pine forests, the evergreen shrublands (maquis), the low scrubland vegetation called phrygana and the grasslands (Athanasiou and Xanthopoulos 2013). As the fuel characteristics are important for the creation of firebrands and the characteristics of the fuel bed where firebrands land affect the probability of ignition, in addition to the FMC, the objective set for this study was to examine the occurrence and characteristics of spotting in three main fuel types in Greece, namely maquis, phrygana and grasses, especially in relation to the prevailing $\mathrm{RH}$, since this affects the FMC of the dead fuels. Most of the work has been carried out as part of the Ph.D. dissertation of the first author (Athanasiou 2015).

\section{Methods}

Systematic observation, recording and measurements of spotting on maquis, phryganic areas and grass during the spread of wildfires, started in 2007 in Greece and continues until today. The procedure followed has been described in Athanasiou and Xanthopoulos (2010). An initial data set of 75 cases was analysed and preliminary findings were presented in 2013 (Athanasiou and Xanthopoulos 2013). Ninety-one (91) additional spotting observations that were collected during the following fire seasons, resulted in a total of 166 cases in which the phenomenon was either present or absent, presenting an opportunity for testing and extending the initial conclusions. The length of observation for each case varied from at least five minutes to almost half an hour, depending on the conditions and the potential risk.

The database that was developed, consists of 166 spotting observations $(n=166)$ that include information about a) the number of the spot fires $(\mathrm{N \kappa}), \mathrm{b})$ the in situ measured $\mathrm{RH}$ values, c) the wind speed at the height of $10 \mathrm{~m}\left(\mathrm{Wind}_{10 \mathrm{~m}}, \mathrm{~km} / \mathrm{h}\right)$ and at eye level (calculating one from the other, depending on which of the two was actually measured), d) the forest fuel type where the firebrands had landed, e) the maximum spotting distance from the fire perimeter $(\mathrm{D} \kappa, \mathrm{m}), \mathrm{f})$ the fire perimeter segment (head or flank) where the firebrands came from, and g) the fire type, namely surface, passive crown, active crown and plume dominated fire during the spread of which the measurements had been conducted (Figure 1). 

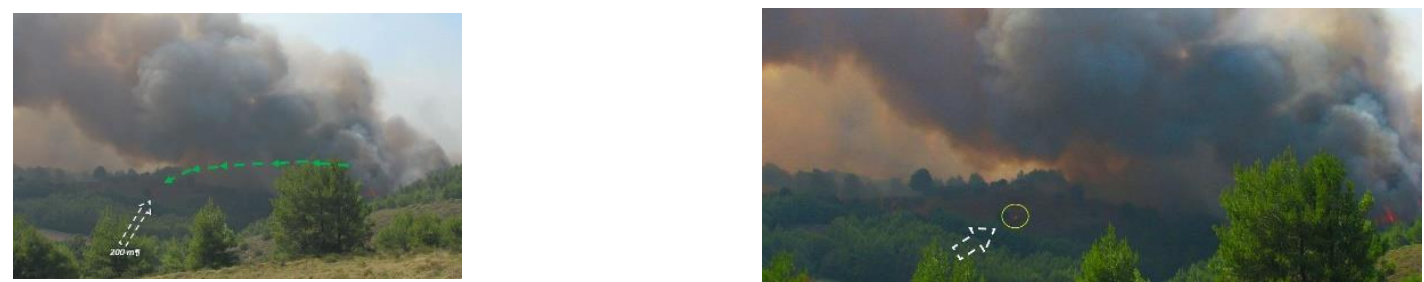

a. The first spot fire is recorded at 15:23:56 at a distance of $200 \mathrm{~m}$

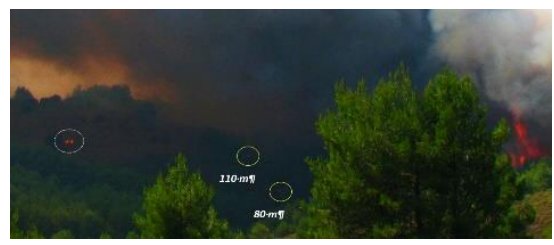

b. Two more spot fires at 15:24:04 at 80 and $110 \mathrm{~m}$ (while the first one at the left is growing)

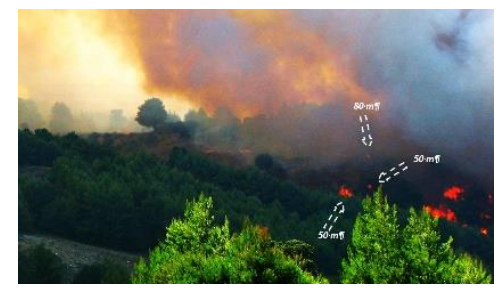

d. $\quad$ Three more spot fires at 15:26:54 at 50 and $80 \mathrm{~m}$ (in total, eleven spot fires recorded, within a period of 2 minutes and 58 seconds)

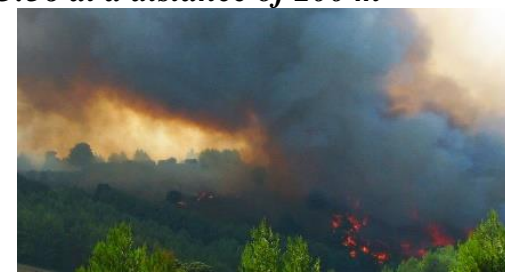

c. $\quad$ Five more spot fires have occured at 180, 200, 230 and $240 \mathrm{~m}$ and some of them have already merged, two minutes and six seconds later (at 15:26:10).

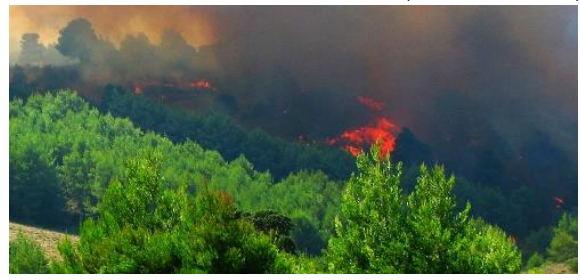

e. Wildfire evolution at 15:28:10

Figure 1 - Spot fires $(N \kappa=11$ \& $D \kappa=240 \mathrm{~m})$ recorded on a $84 \%$ slope, mainly covered by Sarcopoterium spinosum and Cistus spp. (phryganic vegetation), while a wind driven passive crown wildfire spreads through an Aleppo pine stand. Weather conditions: $T=29^{\circ} \mathrm{C}, \mathrm{RH}=43.5 \%$, Wind speed at eye level $=15 \mathrm{~km} / \mathrm{h}$

\section{Analysis}

Meteorological measurements and the relative necessary information about month and time of day, fuels and topography that had been collected on site, were utilised for calculating fine (1-h) dead Fuel Moisture Content (FDFMC, \%) values by using Rothermel's methodology (1983). The database was analysed first by examining the correlation of RH and FDFMC values with the Nא for the three fuel types. An ordinal variable named $\mathrm{K} \kappa$ was created in order to represent the following four empirical classes: a) no spotting $(\mathrm{N} \kappa=0, \mathrm{~K} \kappa=0)$, b) rare spotting $(\mathrm{N} \kappa<3, \mathrm{~K} \kappa=1)$, c) limited spotting $(3 \leq \mathrm{N} \kappa \leq 9$, $\mathrm{K} \kappa=2)$ and d) profuse/massive spotting $(\mathrm{N} \kappa \geq 10, \mathrm{~K} \kappa=3)$. The $\mathrm{N} \kappa$ and the D $\kappa$ were also examined for correlation with both the fire type and the fire perimeter segment on which they had been observed. For the observations/records where $\mathrm{N \kappa}>1$, the $\mathrm{D} \kappa$ value was the distance of the farthest spot fire from the fire perimeter (e.g. Figure 1).

\section{Results}

At RH values higher than $46 \%$, no spotting ignition was recorded. Massive spotting that triggered extreme fire behaviour, was documented for $\mathrm{RH}$ values lower than 17\%. The RH and FDFMC thresholds for spotting occurrence that were found, for the three forest fuel types on which the firebrands landed, are reported in Table 1. The descriptive statistics of $\mathrm{N} \kappa$ and $\mathrm{D} \kappa$ in relation to both the fire type and the fire perimeter segment, are also presented in Table 2 and 3, respectively. Dк values were only available for 58 of the 67 cases in which spotting was observed. 
Table 1 - Ranges of values and thresholds of RH and FDFMC for spotting occurrence, on maquis, phrygana and grass

\begin{tabular}{|c|l|l|c|c|c|}
\hline \multicolumn{2}{|l|}{} & & \multicolumn{4}{|c|}{$\mathrm{n}-\mathrm{RH}-$ FDFMC } \\
\hline RH - FDFMC & $\mathrm{K} \kappa$ & $\mathrm{n}$ & Maquis & $\begin{array}{c}\text { Phrygana } \\
\text { (Sarcopoterium spinosum })\end{array}$ & Grass \\
\hline $\begin{array}{c}(15-62.5)- \\
(4-14)\end{array}$ & 0 & 99 & $43-(15-62.5)-(4-14)$ & $29-(15-50)-(4-12)$ & $\begin{array}{c}27-(23.8-55)-(4- \\
11)\end{array}$ \\
\hline $\begin{array}{c}(15-46)- \\
(3-11)\end{array}$ & 1 & 31 & $9-(20-38.5)-(4-11)$ & $15-(15-46)-(3-10)$ & $7-(16-31)-(3-6)$ \\
\hline $\begin{array}{c}(14-35)- \\
(2-9)\end{array}$ & 2 & 18 & $7-(18-33)-(4-8)$ & $4-(34.5-35)-(6-9)$ & $7-(14-30)-(2-7)$ \\
\hline $\begin{array}{c}(13-46)- \\
(3-8)\end{array}$ & 3 & 18 & $6-(16-21.4)-(3-7)$ & $1-(43.5)-(8)$ & $11-(13-46)-(3-8)$ \\
\hline Total: & 166 & 65 & 49 & 52 \\
\hline
\end{tabular}

Table 2 - Descriptive statistics of Nא, per fire type and perimeter segment for the 67 cases with spotting

\begin{tabular}{|c|c|c|c|c|c|c|}
\hline & \multicolumn{2}{|c|}{$\begin{array}{l}\text { Surface } \\
(n=22)\end{array}$} & \multicolumn{2}{|c|}{$\begin{array}{l}\text { Passive crown } \\
\quad(n=21)\end{array}$} & \multirow{2}{*}{$\begin{array}{c}\text { Active crown } \\
\text { (wind driven) }(\mathrm{n}=7) \\
\begin{array}{c}\text { Head } \\
(\mathrm{n}=7)\end{array}\end{array}$} & \multirow{2}{*}{$\begin{array}{c}\text { Crown (plume) } \\
\qquad(\mathrm{n}=17) \\
(\mathrm{n}=17)\end{array}$} \\
\hline $\mathrm{N}_{\kappa}$ & $\begin{array}{l}\text { Flank } \\
(\mathrm{n}=7)\end{array}$ & $\begin{array}{l}\text { Head } \\
(n=15)\end{array}$ & $\begin{array}{l}\text { Flank } \\
(\mathrm{n}=7)\end{array}$ & $\begin{array}{c}\text { Head } \\
(n=14)\end{array}$ & & \\
\hline Mean value & 1 & 2 & 3 & 5 & 3 & 21 \\
\hline Median & 1 & 1 & 3 & 4 & 2 & 22 \\
\hline Mode & 1 & 1 & 3 & 1 & 1 & 30 \\
\hline Std. Dev. & 1 & 2 & 2 & 6 & 2 & 9 \\
\hline Minimum & 1 & 1 & 1 & 1 & 1 & 5 \\
\hline Maximum & 3 & 8 & 7 & 22 & 6 & 30 \\
\hline Wind $_{10 \mathrm{~m}}$ & & $8-30$ & & 6-111 & $10-26$ & $0-27$ \\
\hline RH & $16-42$ & $15-46$ & $20-35$ & $14-46$ & $20-35$ & $13-21$ \\
\hline FDFMC & $3-7$ & $3-10$ & $4-9$ & $2-11$ & $4-9$ & $3-7$ \\
\hline
\end{tabular}

Table 3 - Descriptive statistics of $D_{k}$, per fire type and perimeter segment $(n=58)$

\begin{tabular}{|c|c|c|c|c|c|c|}
\hline \multirow[b]{2}{*}{$\mathrm{D}_{\kappa}(\mathrm{m})$} & \multicolumn{2}{|c|}{ Surface $(n=22)$} & \multicolumn{2}{|c|}{ Passive crown $(n=17)$} & \multirow{2}{*}{\begin{tabular}{|c|}
$\begin{array}{c}\text { Active crown } \\
\text { (wind-driven) }(\mathrm{n}=7)\end{array}$ \\
Head \\
$(\mathrm{n}=7)$
\end{tabular}} & \multirow{2}{*}{$\begin{array}{c}\text { Crown (plume)* } \\
(\mathrm{n}=12) \\
\\
(\mathrm{n}=12)\end{array}$} \\
\hline & $\begin{array}{l}\text { Flank } \\
(\mathrm{n}=7)\end{array}$ & $\begin{array}{c}\text { Head } \\
(\mathrm{n}=15)\end{array}$ & $\begin{array}{l}\text { Flank } \\
(\mathrm{n}=6)\end{array}$ & $\begin{array}{c}\text { Head } \\
(\mathrm{n}=11)\end{array}$ & & \\
\hline Mean value & 51 & 132 & 71 & 118 & 229 & 392 \\
\hline Median & 20 & 70 & 60 & 100 & 250 & 250 \\
\hline Mode & 15 & 10 & N/A & 100 & 250 & 200 \\
\hline Std. Dev. & 58 & 143 & 48 & 85 & 175 & 308 \\
\hline Minimum & 10 & 5 & 15 & 20 & 50 & 150 \\
\hline Maximum & 150 & 500 & 150 & 300 & 500 & 1,200 \\
\hline Wind $_{10 \mathrm{~m}}$ & & $8-30$ & & $6-36$ & $10-26$ & $0-27$ \\
\hline RH & $16-42$ & $15-46$ & $20-35$ & $15-46$ & $20-35$ & $13-18$ \\
\hline FDFMC & $3-7$ & $3-10$ & $4-9$ & $3-11$ & $4-9$ & $3-6$ \\
\hline
\end{tabular}

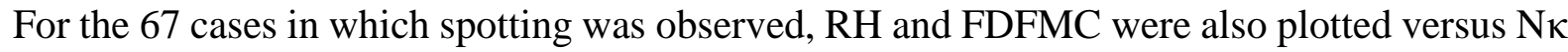
(Figure $2 \& 3$ ). 
Advances in Forest Fire Research 2018 - D. X. Viegas (Ed.)

Chapter 3 - Fire Management

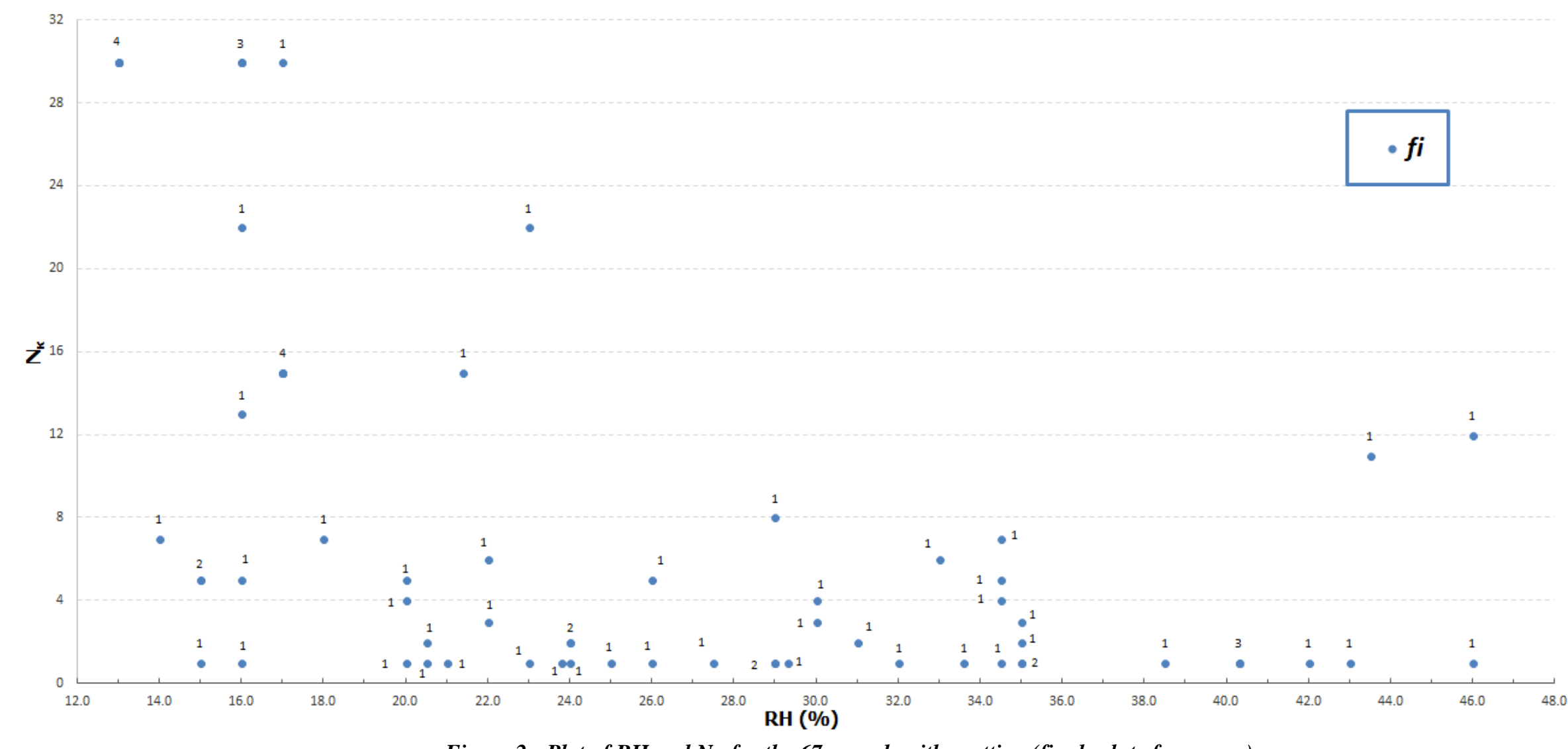

Figure 2 - Plot of $\mathrm{RH}$ and Nא for the 67 records with spotting (fi: absolute frequency) 


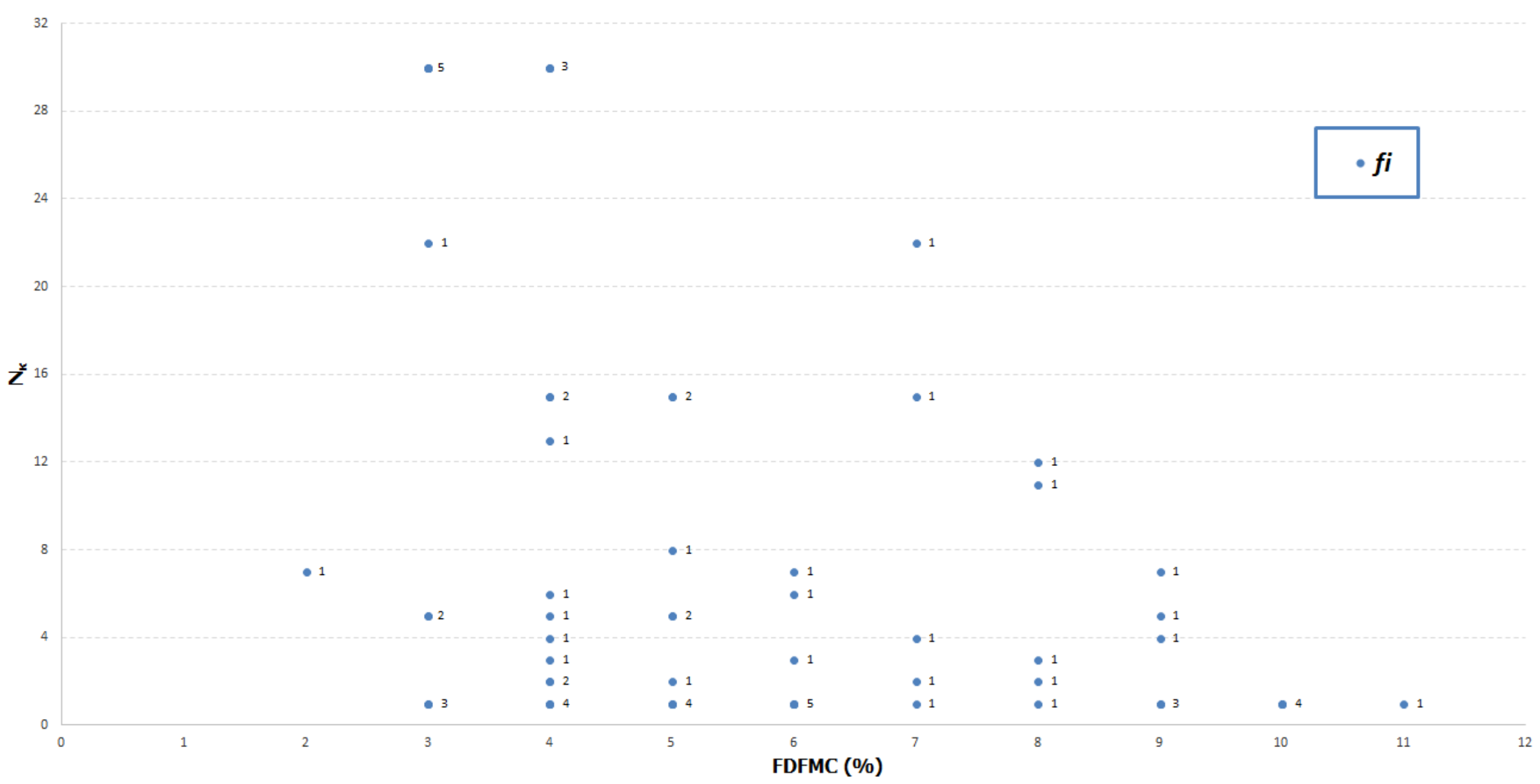

Figure 3 - Plot of FDFMC and Nא for the 67 records with spotting (fi: absolute frequency) 


\section{Discussion}

The maximum $\mathrm{RH}$ value at which spotting occurred $(\mathrm{N} \kappa=1)$ on maquis, was $38.5 \%$ (Table 1, Figure 2 ) and the corresponding calculated FDFMC value was $11 \%$ (Figure 3). The RH and FDFMC thresholds were $46 \%$ and $10 \%(\mathrm{~N} \kappa=1)$ for phrygana and $46 \%$ and $8 \%$ for grass $(\mathrm{N} \kappa=12)$. Regarding phrygana, it is worth noting that there was also one observation (Figure 1) of $K \kappa=3$ spotting class $(\mathrm{N} \kappa=11)$, at relatively high $\mathrm{RH}$ and FDFMC values, $43.5 \%$ and $8 \%$ respectively. In this case, the radiation emitted against the fuel bed, from the leaning smoke column, played a crucial role in preheating the fuels including the fine dead ones (Figure 1). Moreover, regarding the previously mentioned maximum RH and FDFMC datapoint for grass, 12 spot fires were recorded on a grassland, at $\mathrm{RH}=46 \%$ (Figure 2) and FDFMC $=8 \%$ (Figure 3), at a DK of $30 \mathrm{~m}$. The fire brands originated from a torching Pinus halepensis tree and one of them broke into smaller ones upon landing. According to Gould et al. (2007) this is a potentially important notification, and it should be included in any future analysis if available.

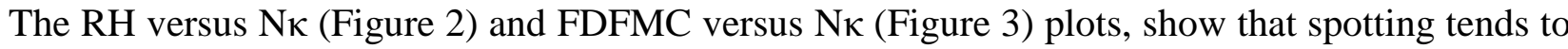
be rare when RH $>40 \%$ or when FDFMC $>10 \%$. The former trend is consistent with Weir's (2004) conclusion who examined 99 prescribed fires and found that spotting occurrence was very rare when $\mathrm{RH}$ exceeded $40 \%$ The latter one is in general agreement with the finding of Manzello et al. (2006) that embers with mass of $0.5 \mathrm{gr}$ could ignite pine needles with fuel moisture of $11 \%$ or less and with the finding of Ellis (2000) that for fine fuel moistures below 9\%, flaming embers with mass between 0.7 and 1.8 gr had a $100 \%$ probability of igniting the Monterey pine litter while glowing ones had lower probabilities. With a light wind $(1 \mathrm{~m} / \mathrm{sec})$ the probability of ignition was found to be about $20 \%$ at fine fuel moisture content of $9 \%$ and approximately $65 \%$ at a fine fuel moisture content of $3.5 \%$ (Ellis 2000).

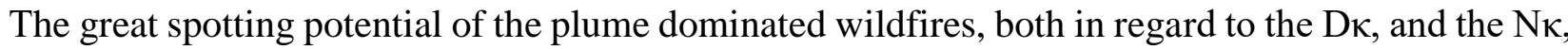
was confirmed (Table $2 \& 3$ ). Future modeling of the shed-vortex transport (Berlad and Lee 1968) and of the plumes' characteristics, may shed light into the long-distance transport aspect for this fire type. Regarding wind driven fires, Wind ${ }_{10 \mathrm{~m}}$ was not found to be a Dא predictor, not even a poor one, for the "head spread" subset. A possible reason is because a fire brand does not always originate at the fire perimeter, so the total horizontal distance it has traveled, is not known and is not necessarily equal to Dк (the distance between the fire perimeter and the farthest recorded spot fire). Furthermore, in addition to the ambient atmospheric conditions, the trajectories of fire brands are also affected by the tilted or vertical turbulence and currents of the convection column.

Additionally, the spot fires that were documented at the flanks of surface and passive crown fires, were not in a windless environment and there was a component of wind of unknown velocity and direction that temporarily drove them. Moreover, fire behavior is sometimes a poor predictor of spotting distance or number of spot fires: as found by Racher (2003), wildfires producing the most distant or numerous landing embers are not always those with the greater rate of spread, flame height or flame depth zone.

The analysis of the subset of 67 records of spotting occurrence did not show a strong correlation between Nא and RH or FDFMC. Tables 1, 2 and 3 as well as Figures 2 and 3, may offer some guidelines and relative practical advice to firefighters and fire behaviour practitioners but they are not predictive tools. Number and size of embers produced by various fuel types, is essential information, in order to estimate how many embers could be carried downwind and how far downwind they will go, to determine whether spotting ( $\mathrm{N \kappa}$ and $\mathrm{D \kappa}$ ) will affect the fire rate of spread and to assess whether the spot fires will be numerous enough to merge readily. According to the field observations, the patterns of spatial distribution of spot fires vary, depending on the fire segment the firebrands originate from, the wind field and the landscape (Figure $4 \mathrm{a} \& 4 \mathrm{~b}$ ). 


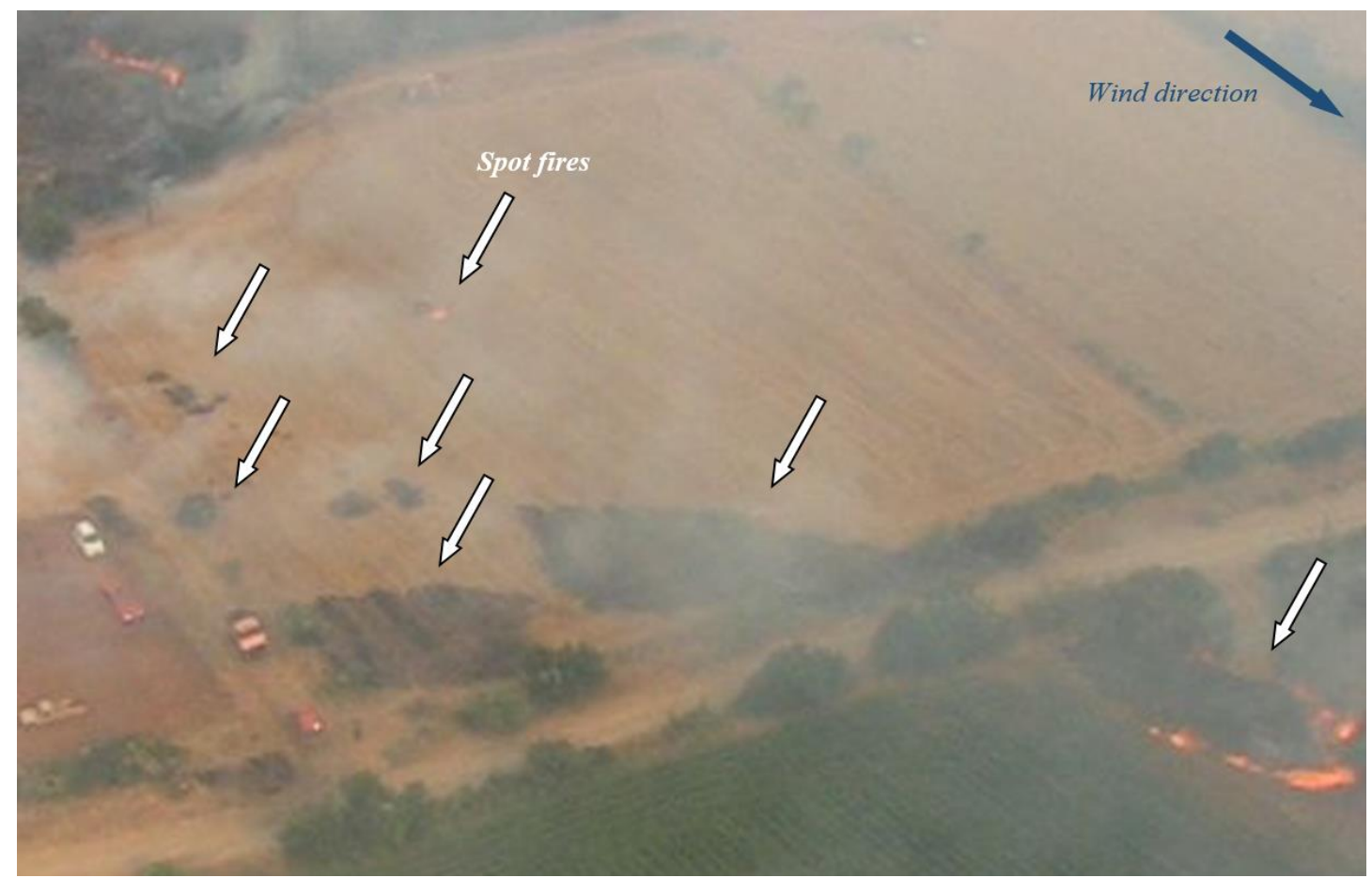

Figure 4a - An along-wind pattern of landing embers, on grass, downwind from a surface head fire

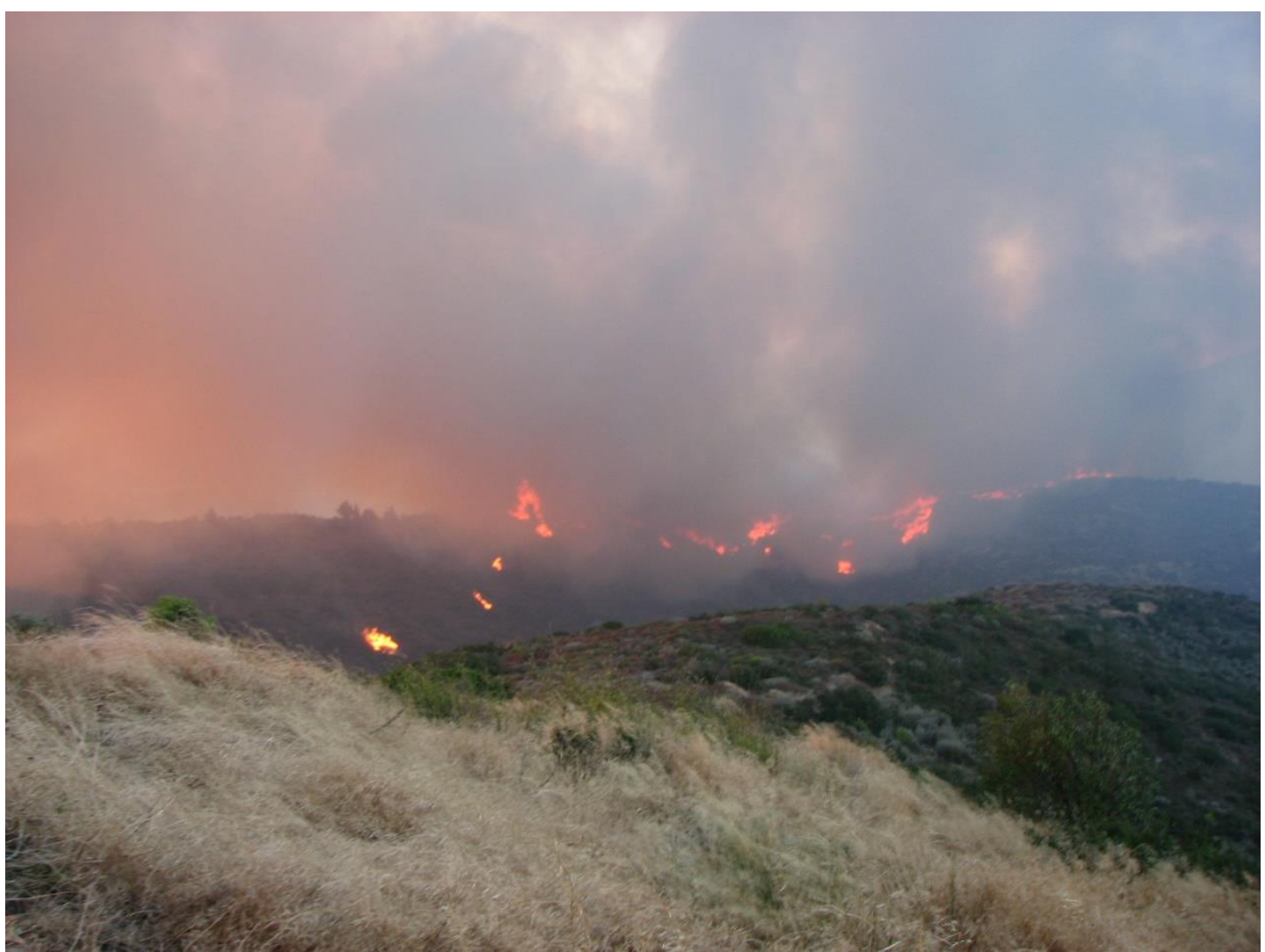

Figure $4 b$ - An across-wind pattern of landing embers, on phrygana beyond the flank of a surface wildfire that spreads through rough landscape

The along-wind pattern of groups of spot fires has been observed to form a roughly elliptical shape (Figure $4 \mathrm{a}$ ) and seems to be more predictable, while the across-wind one (Figure $4 \mathrm{~b}$ ) is irregular. Although these patterns have not yet been thoroughly described, they may allow firefighters to get a feeling on what to expect, a practically useful information: those patterns may play a crucial role in 
the behavior as the proximity among the spot fires affects their merging rate and the overall effective rate of spread and intensity. As proposed by Gould et al. (2007), they can be studied in the field, leading to the development of empirical functions.

\section{Conclusions}

The findings of the work presented here is that no spotting ignition was recorded on maquis, phrygana and Mediterranean grasslands, at $\mathrm{RH}$ values higher than $46 \%$ and that massive spotting that triggered extreme fire behaviour, was documented for RH values lower than $17 \%$.

The RH threshold below which a spot fire is most likely to occur seems to be close to the value of $40 \%$. However, it was also observed that a significant number of spot fires may take place even if $\mathrm{RH}$ values range between $40 \%$ and $46 \%$. The finding that this is most likely to occur on fine fuels (phrygana and grass) should be taken into consideration, in operational firefighting.

The patterns of the spatial distribution of spot fires, and their basic characteristics in head and flank fires, can be included in practical guidelines about spotting

Future work is expected to shed additional light on the issues discussed in this paper, as field data continue being collected, ultimately improving fire behaviour prediction and firefighter safety in Greece.

\section{Acknowledgements}

The research reported here is part of the Ph.D. thesis of the first author. It was sponsored, in part, by the International Association of Wildland Fire (IAWF) through the Doctoral Student Scholarship Award for 2014. Participation of the second author was in the frame of the project MedWildFireLab ("Global Change Impacts on Wildland Fire Behaviour and Uses in Mediterranean Forest Ecosystems, towards a «wall less» Mediterranean Wildland Fire Laboratory”) a European ERANet FORESTERRA project with funding from the General Direction for the Development and Protection of Forests and Agro-environment of the Greek Ministry of Environment and Energy.

\section{Bibliography}

Albini F.A., 1979. Spot fire distance from burning trees: a predictive model. USDA Forest Service, Intermountain Forest and Range Experiment Station, Technical Report INT-56. (Ogden, UT).

Alexander, M.E. 2009. Some pragmatic thoughts on the prediction of spotting in wildland fires. MITACS/GEOIDE Conference on Forest Fire Modelling, June 22-23, 2009 - Hinton, AB.

Athanasiou, M. and G. Xanthopoulos 2010. Fire behaviour of the large fires of 2007 in Greece. In proceedings of the 6th International Conference on Forest Fire Research, 15-18 November 2010, Coimbra, Portugal. D.G. Viegas, Editor. ADAI/CEIF, University of Coimbra, Portugal. Abstract p. 336, full text on CD.

Athanasiou M. and G. Xanthopoulos 2013. Observations of the spotting phenomenon, in wildfires in Greece. 30-40 p. In proceedings of the 16th National Forestry Conference, October 6-9, 2013, Thessaloniki, Greece. Hellenic Forestry Society. 1144 p. (in Greek).

Athanasiou, M. 2015. Development of an optimal methodology for forecasting forest fire behaviour in Greece. PhD dissertation, Department of Geology and Geoenvironment, National and Kapodistrian University of Athens, 408 p. (In Greek with English abstract).

Berlad AL, Lee SL 1968. Long-range spotting. Combustion and Flame 12, 172-174.

Bushfire CRC. 2009. Victorian Bushfires 2009 Research Taskforce. October 2009. Final Report. 
Byram, G.M. 1959. Combustion of forest fuels; Forest fire behavior. in Davis, K.P., ed. Forest fire: Control and use. New York: McGraw-Hill: 61-89, 90-123.

Ellis, P.F.M. 2000. The aerodynamic combustion characteristics of eucalypt bark - a firebrand study. A Thesis submitted to the Australian National University for the Degree of Doctor of Philosophy.

Ellis, P.F.M. 2012. A review of empirical studies of firebrand behavior. CSIRO Ecosystem Science and CSIRO Climate Adaptation Flagship.

Ganteaume A., Lampin-Maillet C., Guijarro M., Hernando C., Jappiot M., Fonturbel T., PerezGorostiaga P. and J.A. Vega. 2009. Spot fires: fuel bed flammability and capability of firebrands to ignite fuel beds. International Journal of Wildland Fire, 18, 951-969.

Gould, J.S. McCaw, W.L. Cheney N.P. Ellis, P.F. Knight, I.K. Sullivan, A.L. 2007. Project Vesta-Fire in dry eucalypt forests: fuel structure, fuel dynamics, and fire behaviour. Perth, WA: Ensis-CSIRO, Canberra ACT and Department of Environment and Conservation. 218 p.

Hadden, R., Scott, S., 2011. Ignition of Combustible Fuel Beds by Hot Particles: An Experimental and Theoretical Study. Fire Technology 47:341-355.

Koo, E., Pagni, P.J., Weise, D.R., Woycheese, J.P., 2010. Firebrands and spotting ignition in largescale fires. International Journal of Wildland Fire 19:818-843.

Manzello, S.L., Cleary, T.G., Shields, J.R., and Yang, J. C. 2006. On the ignition of fuel beds by firebrands. Fire and Materials 30: 77-87.

Racher, B. 2003. Prescription development for burning two volatile fuel types. Lubbock. TX: Texas Tech University. 72 p. Ph.D. dissertation.

Rothermel, R.C., 1983. How to predict the spread and intensity of forest and range fires. Gen. Tech. Rep. INT-143. Ogden, UT: U.S. Department of Agriculture, Forest Service, Intermountain Forest and Range Experiment Station. $161 \mathrm{p}$.

Van Wagner, C.E. 1988. Effect of slope on fires spreading downhill. Can. J. For. Res. 18:818-820.

Weir, John. 2004. Probability of Spot Fires During Prescribed Burns. Fire Management Today. 64. 24-26. 